\title{
Collaborative Skills of Pre-service Mathematics Teachers in Blended Learning
}

\author{
Ulfa Lu'luilmaknun', Karin Selma Al Kautsar2*, Ratih Ayu Apsari' ${ }^{3}$, Tabita Wahyu Triutami', \\ Nourma Pramestie Wulandari ${ }^{5}$ \\ 1,3,4,5Mathematics Education, Universitas Mataram, Indonesia \\ 2 Faculty of Education Curriculum and Pedagogy, Universiti Kebangsaan Malaysia, Malaysia \\ 1ulfa1@unram.ac.id, 2P103044@siswa.ukm.edu.my ${ }^{3}$ ra.apsari@unram.ac.id, \\ 4tabita.triutami@unram.ac.id, 5 nourmapw@unram.ac.id
}

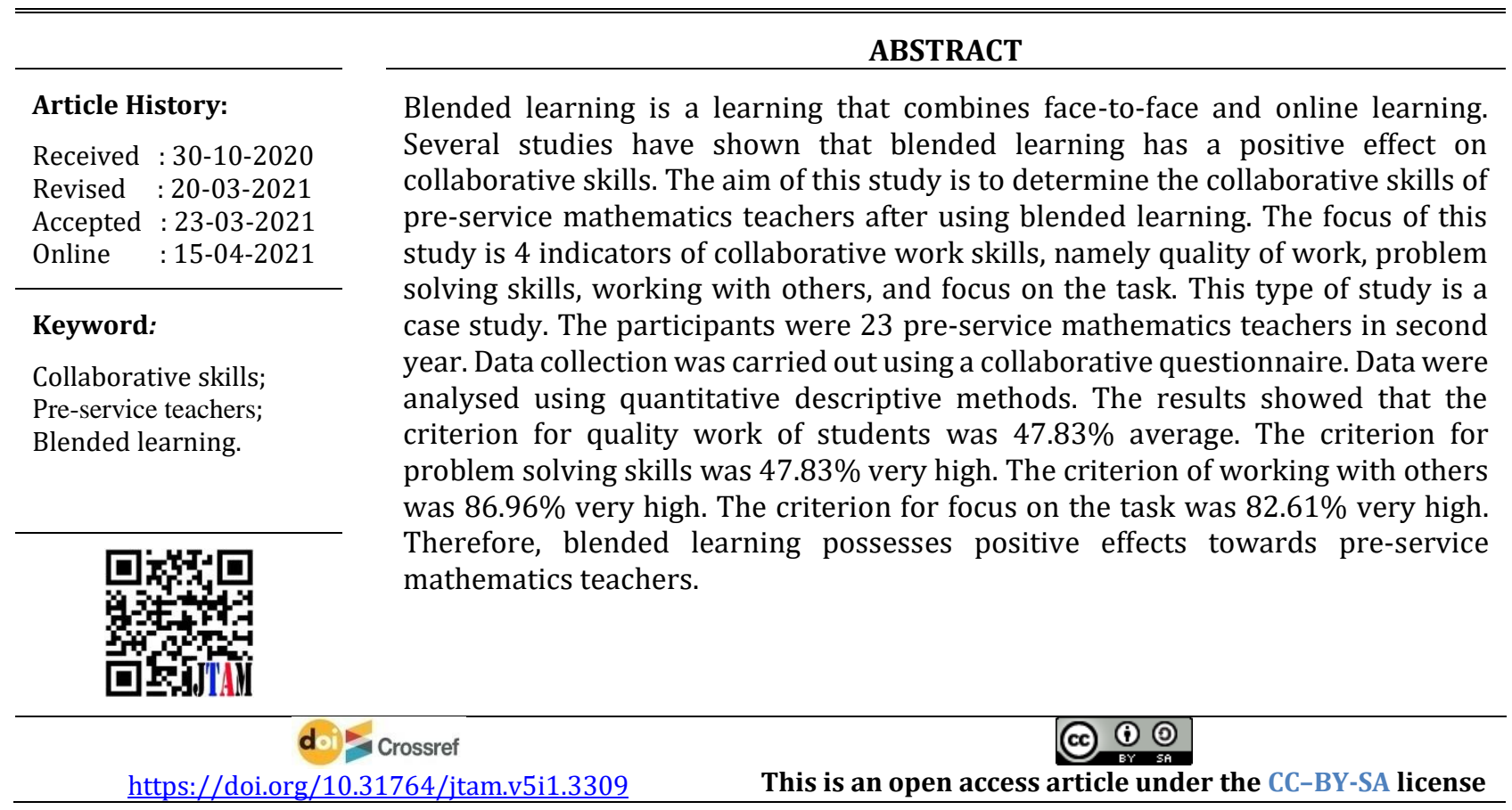

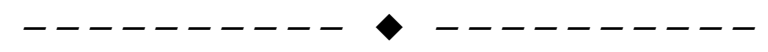

\section{A. INTRODUCTION}

In the $21^{\text {st }}$ century, there are four important skills possessed by students namely communication, collaboration, critical thinking and problem solving, and creative and innovative.it is in line with what is stated by Erdoğan (2019) that students should be competent and proficient as communicators, creators, critical thinkers, and collaborators to compete in global society. Therefore, collaborative skills are important to be possessed, not only for higher students but also pre-service mathematics teachers. Collaborative learning is a teaching methodology commonly used (De Hei, Strijbos, Sjoer, \& Admiraal, 2015) . It is considered as a key component in facilitating active learning (Beichner, 2014) . Collaborative learning becomes more important for contemporary and wider learning environments for the purpose of achieving better pedagogical results (Bruffee, 1984; Pang, Lau, Seah, Cheong, \& Low, 2018). It is increasingly becoming important in schools and organizations (Zambrano, Kirschner, Sweller, \& Kirschner, 2019). 
Collaborative learning is often defined as two or more people working together towards a shared learning goal (Jeong \& Hmelo-Silver, 2016). Collaborative learning expectations of students not only collect their contributions, students work with one another towards a common goal, weaving together their work that is prepared independently (Falcione et al., 2019; Barkley, Cross, \& Major, 2014).

From "I Rubric: Collaborative Work Skills rubric", indicator from collaborative work skills, namely quality of work, problem solving skills, working with others, and focus on the task. Quality of work namely to increase the quality of work and directs others to achieve the same quality. Problem solving skills, namely how students actively seek and suggest solutions to a problem. Working with others, namely listening to opinions, sharing, and supporting others, as well as building good cooperation. Focus on the task is what is done on the task and what needs to be done, promotes independent learning, and how effective group leadership.

However, there are some students that still have low collaborative skill. A study conducted by Le, Janssen, \& Wubbels (2017) showed that some teachers found that their students were predominantly unable to implement collaborative skills effectively. The most common comment from teacher such as most of the students were unable to work together effectively in group since they lack of experiences to do so in the previous levels of their education (primary and secondary school). Collaborative skill is necessary to be possessed by students in a learning process because it is beneficial to support the learning achievement. Collaborative learning involves active student involvement, small group learning, and the development of thinking skills (Robbins \& Hoggan, 2019). Collaborative learning requires students to interact with peers to develop conceptual connections and alternative understanding methods (Laal \& Laal, 2012). Students who have collaborative abilities can make individual contributions at different times or places, or it can be done separately from other team members at the same time or place (Falcione et al., 2019). That is, students can collaborate in learning with friends anywhere and anytime. Technology-based learning, for example online learning can be one of the media for learning anywhere and anytime.

Technology-based learning has been applied in several learning activities, including mathematics learning. Some researchers have shown the positive effects of technology-based learning on learning. Technology provides opportunities for students to engage in joint assignments, communication, sharing knowledge, actively participating in the learning process, and participating in developing groups (Jeong \& Hmelo-Silver, 2016). Collaborative learning is suitable to be combined with technology learning (Fakomogbon \& Bolaji, 2020). Students who receive active learning classes have a higher level of collaborative learning (Clinton \& Wilson, 2019) and technology is one of the learning media that promotes active learning. Technology has a positive effect on collaborative learning (Giannakos \& Darra, 2019). Online courses increase opportunities for collaborative learning (Borba et al., 2016).

Blended learning is learning that combines face-to-face and online learning. It is a learning activity that teaches conventional learning with online learning (30-79\% online learning) (Allen, Seaman, \& Garrett, 2007). It consists of learning methods, tools, and technology both physical and virtual environments (Seraji, Attaran, \& Azizi, 2019). It is a combination of all types of e-learning elements and face-to-face learning (Firat Altay \& Altay, 2019). Blended learning is an innovative concept that is supported by traditional learning in class and technology- 
supported learning, including offline learning and online learning (Lalima \& Lata Dangwal, 2017). Blended learning is a formal education program where students learn more through online learning, with some elements of student control such as time and place (Horn \& Staker, 2014).

Blended learning can be combined in the form of collaboration, both collaboration between students or teachers through possible communication tools such as chat rooms, discussion forums, e-mails, web sites, and cell phones (Ikhwan \& Widodo, 2019). With such learning designs, the ability of collaborative students will increase. Blended learning can help teachers develop technologies suitable for student learning and organize learning for students (Fazal \& Bryant, 2019). Students learning by using blended learning have a better conceptual understanding (Setyaningrum, 2018). Blended learning has a positive effect on students' attitudes and learning outcomes (Lin, Tseng, \& Chiang, 2017). It can increase the independence of learning and collaboration of students (Wahyuni, 2018). Blended learning can enhance student collaboration learning (Laisema, 2018).

From the several descriptions that have been presented, it is the evident that some studies show that blended learning has a positive effect on learning, not least in mathematics learning. One of the benefits of blended learning is to improve students' collaboration skills. Several studies have elaborated on the effects of blended learning on students and there are still a few that examine the effects of blended learning on pre-service mathematics teachers' collaborative skills. Therefore, the aim of this study is to determine the collaborative abilities of mathematics students after using blended learning in terms of collaborative work skills, namely quality of work, problem solving skills, working with others, and focus on the task.

\section{B. METHODS}

This type of study is a case study. The participants were 23 pre-service mathematics teachers in second year at University of Mataram. Learning was carried out during 14 meetings. The learning used was blended learning, where $50 \%$ of learning activities were carried out in the classroom and $50 \%$ of online learning. Learning in the classroom used discussion and question and answer methods, while online learning used the Schoology application. The learning material used in this study was material about the implementation of learning theory in mathematics learning. At each learning meeting in class, one group presented the results of the discussion and the other group responded. Then the continued discussion about the material presented was conducted on online learning.

Data collection was carried out using a collaborative questionnaire. The questionnaire consists of 12 items with 4 indicators of collaborative work skills, namely quality of work, problem solving skills, working with others, and focus on the task. Questionnaire was given after 14 meetings were completed. Data were analysed using quantitative descriptive methods. The data were processed quantitatively in percentage and then were described descriptively.

\section{RESULT AND DISCUSSION}

1. Quality of Work

In quality work of students, students are not only able to work with good quality but also direct their friends to work in good quality. In this research, quality work of students in 
question is how students actively participate in discussions in classroom learning and online learning that has been provided by lecturers, how students actively provide problems regarding material to be discussed together in classroom learning and online learning, and whether students can conclude the results of the discussion.

Some students have been able to actively participate in discussions in classroom learning and online learning. In classroom learning, some students have been able to actively participate in providing examples of the application of learning theories in mathematics learning. In online learning, some students actively respond to lecturer questions on online discussion forums. In addition, some students also actively shared knowledge in the form of text, pictures and videos.

Some students have been able to actively provide problems regarding cases related to learning material. Students can direct classmates to discuss these problems to get the best solution. Then students together can conclude the results of the discussion.

Some students have been able to conclude the results of the discussion well. Students express conclusions or solutions to problems in learning in class. Students who still want to have an opinion on these issues, can continue the discussion on online learning. The criteria for the ability of quality work of students can be seen in Figure 1.

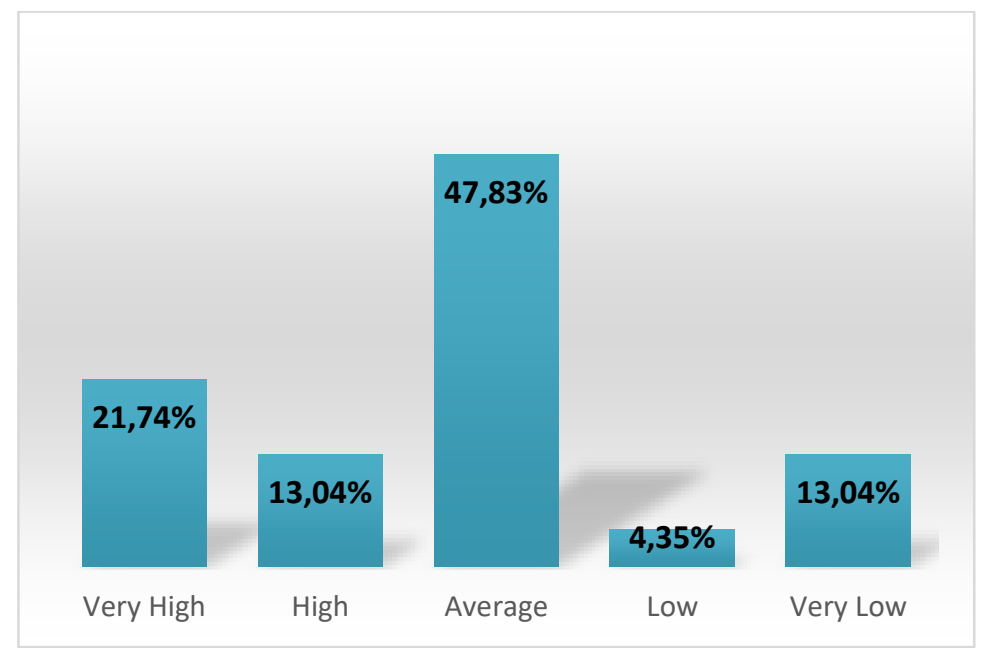

Figure 1. Criteria of Quality Work of Pre-service Mathematics Teachers

In this study, the criteria of quality work of pre-service mathematics teachers meet all the criteria, namely very high, high, average, low, and very low. From Figure 1 it can be seen that almost half of pre-service mathematics teachers have sufficient criteria for quality work of students. This proves that blended learning has an influence on pre-service mathematics teachers' quality of works.

Figure 2 is an example of active participation of pre-service mathematics teachers in online learning. One student gave a problem in an online forum, "What do you know about constructivism and social-cultural learning theory?". Some students respond to problems given by their friends. Student 1 answered "We can define constructivism theory as generative learning, which is the act of creating meaning from what is learned. The difference with behaviouristic theory is that behaviouristic theory understands the nature of learning as a mechanistic activity between stimulus responses, whereas constructivism theory is understanding learning as a human activity to build or create knowledge by giving meaning 
to his knowledge according to his experience. "Student 2 answers" Sociocultural learning theory, emphasizing how individually or students learn with the help of others to solve or solve the problems they face. Sociocultural theory also emphasizes that knowledge possessed by humans comes from society, the environment, and culture. While constructivist theory, emphasizes that students must be more active to develop the knowledge he has. " From Figure 3 it can also be seen that one of the students shared a video link about learning theory in an online forum.

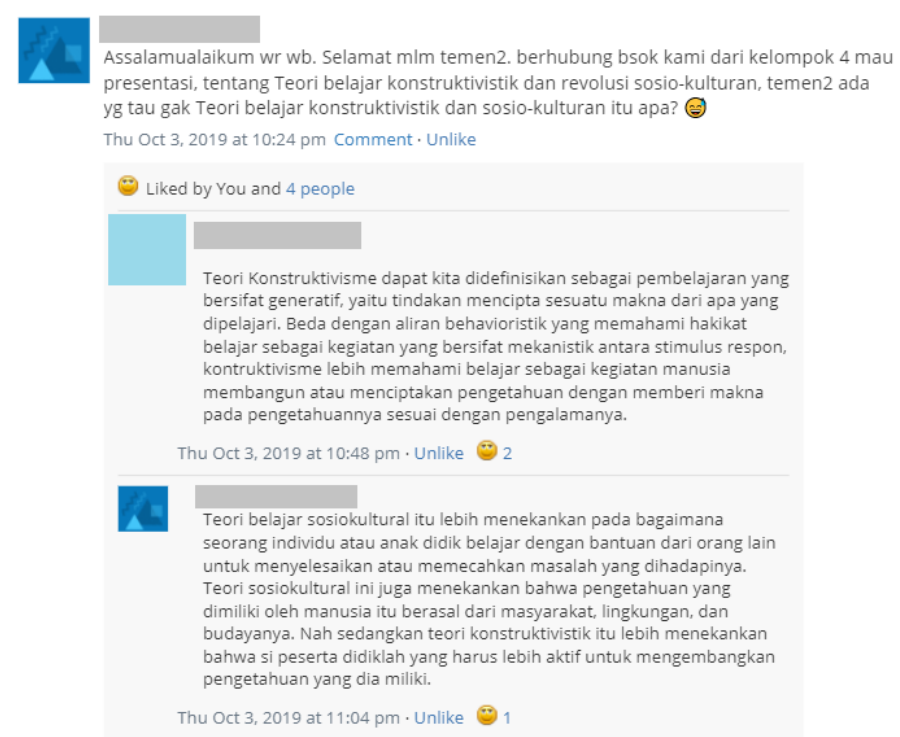

Figure 2. Example of Active Participation of Pre-service Mathematics Teachers

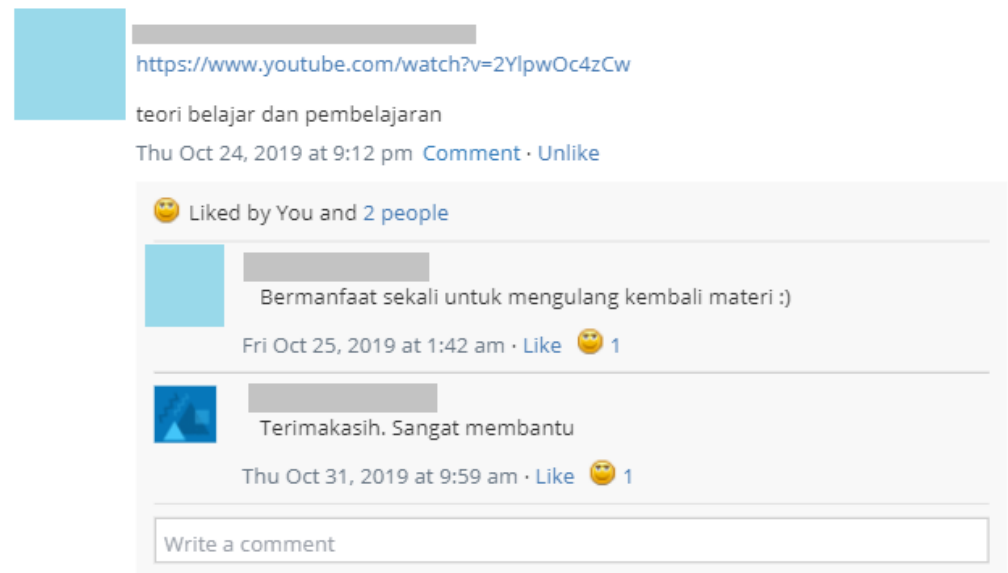

Figure 3. Examples of Pre-service Mathematics Teachers Share Video Links

\section{Problem Solving Skills}

The problem solving skills described in this study are how students actively seek and suggest solutions to a problem from group assignments. Students try to find ideas to find solutions. Students in groups creatively suggest several different solutions then from some of the solutions will be synthesized to form the best conclusions or solutions.

Some students have been able to actively find and suggest solutions. Together with group friends, students exchange opinions and try to find the best solution. In general, the criteria for problem solving skills can be seen in Figure 4. From Figure 4 it can be seen that almost 
half of pre-service mathematics teachers have very high criteria in problem solving skills. There are no pre-service mathematics teachers with low criteria and very low problem solving skills.

Blended learning can be proven that it increases the ability of problem solving from some of the studies. Based on observations during the development research and evaluation process, the application of blended learning to problem solving has a positive effect (Dwiyogo, 2018) and e-learning as a media in blended learning can also help to improve problem solving skills (Lu'luilmaknun \& Wutsqa, 2018). Blended learning can improve students' problem solving skills (Shalihah, Supramono, \& Abdullah, 2019).

There are nine factors that can influence the improvement of problem solving skills with blended learning (Sophonhiranrak, Suwannatthachote, \& Ngudgratoke, 2015). There are four factors affecting the ability of problem solving, namely understanding the challenges, generating ideas, preparing for action, and planning self approach. There are five factors in blended learning, namely learning activities, learning resources, feedback, learning interaction, and evaluation.

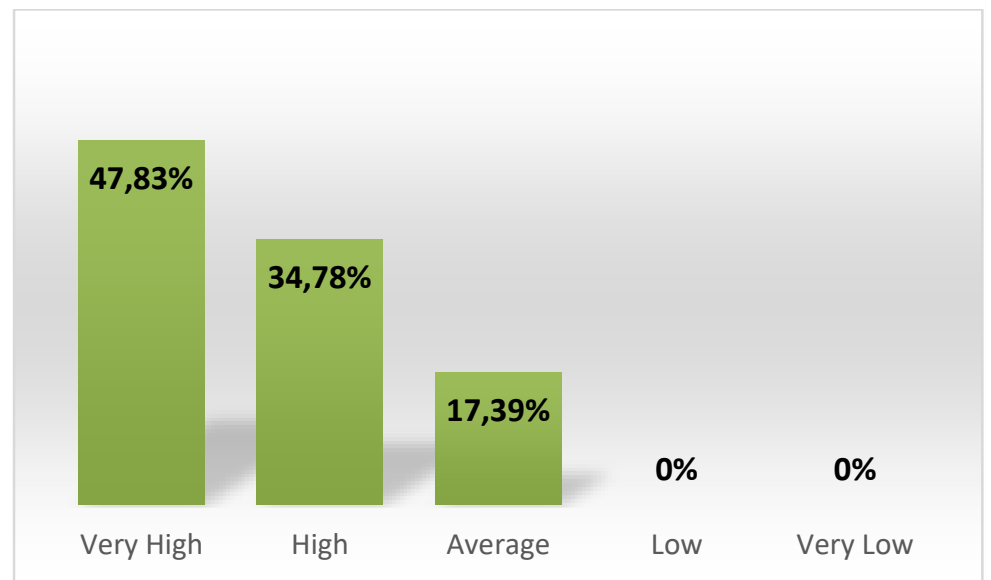

Figure 4. Criteria of Pre-service Mathematics Teachers' Problem Solving Skills

\section{Working with Others}

Working with others referred to in this study is trying to work well with fellow group friends. Good collaboration in groups includes active participation in group assignments, listening to and responding to the opinions of friends of the group. To support team work in blended learning, pre-service mathematics students are facilitated by a discussion forum on the Schoology application to discuss the assignments of each group. In general, the criteria for the ability to work with others students can be seen in Figure 5. 


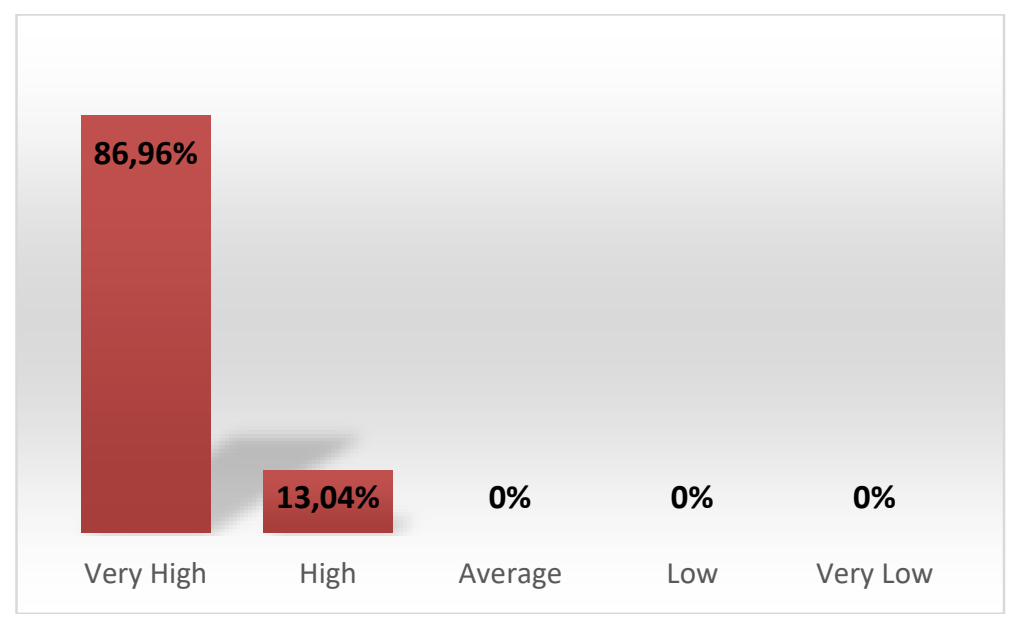

Figure 5. Criteria of Pre-service Mathematics Teachers' Working with Others

From Figure 5, it appears that more than half of pre-service teachers have very high criteria in working with others. There are no pre-service teachers who have average, low, and very low criteria. This proves that blended learning has a great influence on working with others.

\section{Focus on The Task}

Focus on the task in this study referred to student focus on the task that must be done. Students must try to do individual or group assignments on time. In this study, assignments are usually uploaded to online learning applications. In general, the criteria for focus on the task of students can be seen in Figure 4.

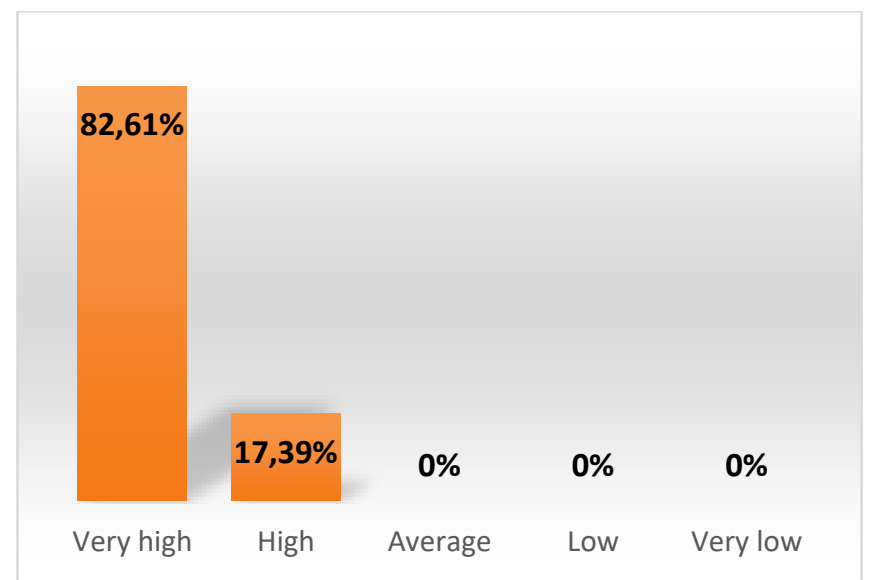

Figure 6. Criteria of Pre-service Mathematics Teachers' Focus on The Task

From Figure 6, it can be seen that more than half of pre-service teachers have very high criteria for focus on the task. There are no pre-service teachers who have average, low, and very low criteria. This proves that blended learning has a great influence on pre-service mathematics teachers' focus on the task. Examples of pre-service mathematics teachers' activities focusing on the task can be seen in Figure 7, where one student uploaded an assignment given by a lecturer at Schoology. 


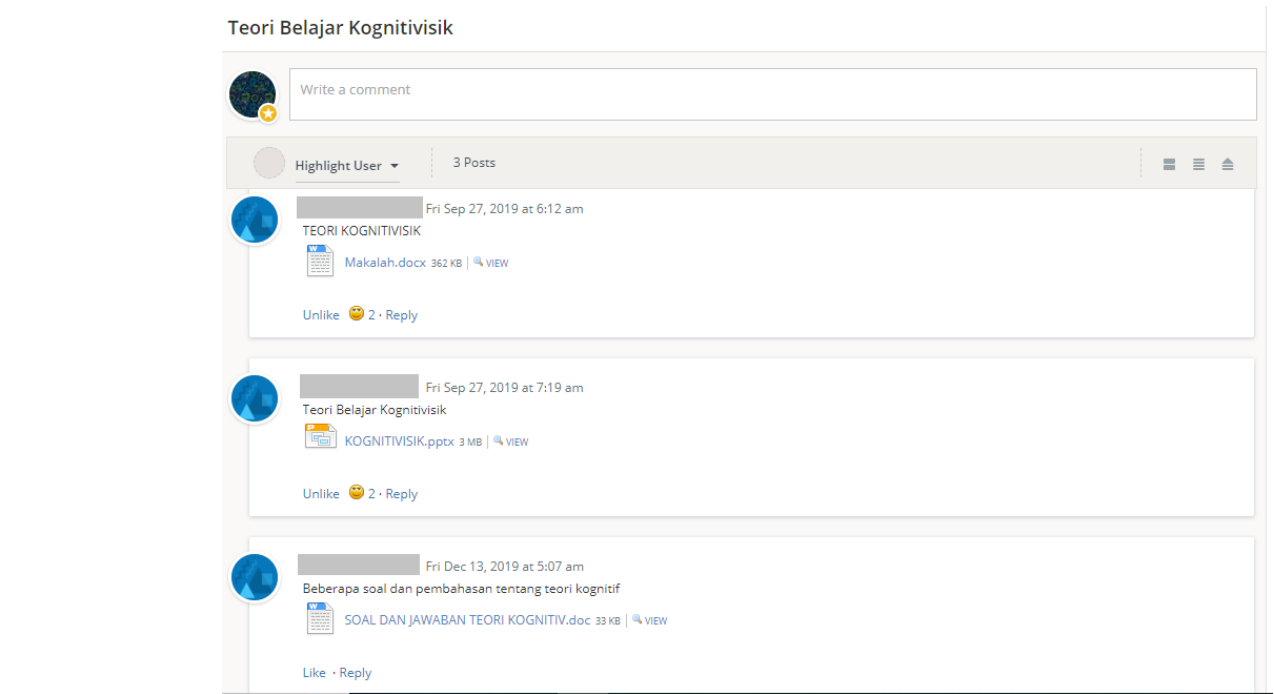

Figure 7. Examples of Pre-service Mathematics Teachers' Activities Focus on The Task

\section{CONCLUSION AND SUGGESTIONS}

Blended learning is a learning activity that emphasizes the combination of face-to-face and online learning. This study aims to determine 4 indicators of collaborative work skills, namely quality of work, problem solving skills, working with others, and focus on the task as the main focus on this study. The results showed that the criteria for quality work of students: $21.74 \%$ very high, $13.04 \%$ high, $47.83 \%$ average, $4.35 \%$ low, and 13.04 very low. The criteria for problem solving skills: $47.83 \%$ very high, 34.78 high, and 17.39 average. The criteria of working with others: $86.96 \%$ very high and $13.04 \%$ high. The criteria for focus on the task: $82.61 \%$ very high and $17.39 \%$ high. Therefore, it can be concluded that blended learning provides positive effects towards pre-service mathematics teachers. The positive significance expected from this study especially for educators is that they can implement blended learning in mathematics while teaching in the class. In the other hand, for the next researcher, they are expected to find effectiveness blended learning in affective aspect.

\section{ACKNOWLEDGEMENT}

Thank to Department of Mathematics Education, Faculty of Education and Teacher Training, University of Mataram for giving the support in this study.

\section{REFERENCES}

Allen, I. E., Seaman, J., \& Garrett, R. (2007). Blending in: The extent and promise of blended education in the United States. In The Sloan Consortium. United States of America: Sloan-C ${ }^{\text {TM. }}$

Barkley, E. F., Cross, K. P., \& Major, C. H. (2014). Collaborative Learning Techniques : A Handbook For College University (2nd Editio, Vol. 0). San Francisco, CA: Jossey-Bass.

Beichner, R. J. (2014). History and Evolution of Active Learning Spaces. In New Directions for Teaching and Learning (pp. 9-16). https://doi.org/10.1002/tl

Borba, M. C., Askar, P., Engelbrecht, J., Gadanidis, G., Llinares, S., \& Aguilar, M. S. (2016). Blended learning, e-learning and mobile learning in mathematics education. $Z d m, 48(5), 589-610$. https://doi.org/10.1007/s11858-016-0798-4

Bruffee, K. A. (1984). Collaborative Learning and the "Conversation of Mankind." College English, 46(7), 635-652. https://doi.org/10.4135/9781412957403.n296

Clinton, V., \& Wilson, N. (2019). More than chalkboards: classroom spaces and collaborative learning attitudes. Learning Environments Research, 22(3), 325-344. https://doi.org/10.1007/s10984019-09287-w 
De Hei, M. S. A., Strijbos, J. W., Sjoer, E., \& Admiraal, W. (2015). Collaborative learning in higher education: lecturers' practices and beliefs. Research Papers in Education, 30(2), 232-247. https://doi.org/10.1080/02671522.2014.908407

Dwiyogo, W. D. (2018). Developing a blended learning-based method for problem-solving in capability learning. TOJET: The Turkish Online Journal of Educational Technology, 17(1), 51-61.

Erdoğan, V. (2019). Integrating 4C skills of 21st century into 4 language skills in EFL classes. International Journal of Education and Research, 7(11), 113-124.

Fakomogbon, M. A., \& Bolaji, H. O. (2020). Effects of Collaborative Learning Styles on Performance of Students in a Ubiquitous Collaborative Mobile Learning Environment. Contemporary Educational Technology, 8(3), 268-279. https://doi.org/10.30935/cedtech/6200

Falcione, S., Campbell, E., McCollum, B., Chamberlain, J., Macias, M., Morsch, L., \& Pinder, C. (2019). Emergence of Different Perspectives of Success in Collaborative Learning. The Canadian Journal for the Scholarship of Teaching and Learning, 10(2). https://doi.org/10.5206/cjsotlrcacea.2019.2.8227

Fazal, M., \& Bryant, M. (2019). Blended Learning in Middle School Math: The Question of Effectiveness. Journal of Online Learning Research, 5(1), 49-64.

Firat Altay, İ., \& Altay, A. (2019). A Review of Studies on Blended Learning in EFL Environment. International Journal of Curriculum and Instruction, 11(1), 125-140.

Giannakos, V., \& Darra, M. (2019). The Contribution of Computer-Supported Collaborative Learning to the Development of Collaboration Between Students: Results of Pilot Implementation in Greek $\begin{array}{lllll}\text { Secondary Education. International Education } & \text { Studies, } & 12(3), & \end{array}$ https://doi.org/10.5539/ies.v12n3p158

Horn, M. B., \& Staker, H. (2014). Blended learning: Using disruptive innovation to improve schools. Francisco: Jossey Bass.

Ikhwan, E. J., \& Widodo, P. (2019). Attitude Conception: The Role of Blended Learning in Environmental Education. Online Submission, 2(6), 53-62. https://doi.org/10.32996/ijllt.2019.2.6.7

Jeong, H., \& Hmelo-Silver, C. E. (2016). Seven Affordances of Computer-Supported Collaborative Learning: How to Support Collaborative Learning? How Can Technologies Help? Educational Psychologist, 51(2), 247-265. https://doi.org/10.1080/00461520.2016.1158654

Laal, M., \& Laal, M. (2012). Collaborative learning: What is it? Procedia - Social and Behavioral Sciences, 31(2011), 491-495. https://doi.org/10.1016/j.sbspro.2011.12.092

Laisema, S. (2018). Development of collaborative blended learning activity on mobile learning to enhance undergraduate students' collaboration skills. Veridian E-Journal, Silpakorn University (Humanities, Social Sciences and Arts), 11(4), 682-699.

Lalima, D., \& Lata Dangwal, K. (2017). Blended Learning: An Innovative Approach. Universal Journal of Educational Research, 5(1), 129-136. https://doi.org/10.13189/ujer.2017.050116

Le, H., Janssen, J., \& Wubbels, T. (2017). Collaborative learning practices: teacher and student perceived obstacles to effective student collaboration. Cambridge Journal of Education, 48(1), 103-122. https://doi.org/10.1080/0305764X.2016.1259389

Lin, Y. W., Tseng, C. L., \& Chiang, P. J. (2017). The effect of blended learning in mathematics course. Eurasia Journal of Mathematics, Science and Technology Education, 13(3), 741-770. https://doi.org/10.12973/eurasia.2017.00641a

Lu'luilmaknun, U., \& Wutsqa, D. U. (2018). The Effectiveness of E-learning Media with Guided Discovery Method from The Perspective of Student's Mathematics Problem Solving Skill. Proceedings of The 5th International Conference On Research, Implementation And Education Of Mathematics And Sciences (5th ICRIEMS), (1), 169-176.

Pang, C., Lau, J., Seah, C. P., Cheong, L., \& Low, A. (2018). Socially challenged collaborative learning of secondary school students in Singapore. Education Sciences, 8(24), 1-10. https://doi.org/10.3390/educsci8010024

Robbins, S., \& Hoggan, C. (2019). Collaborative Learning in Higher Education To Improve Employability: Opportunities and Challenges. New Directions for Adult and Continuing Education, 2019(163), 95108. https://doi.org/10.1002/ace.20344

Seraji, F., Attaran, M., \& Azizi, S. M. (2019). Blended learning researches in Iran: Several fundamental criticisms. Digital Education Review, (36), 190-206. https://doi.org/10.1344/der.2019.36.190- 
206

Setyaningrum, W. (2018). Blended Learning: Does it help students in understanding mathematical concepts? Jurnal Riset Pendidikan Matematika, 5(2), 244-253. https://doi.org/10.21831/jrpm.v5i2.21428

Shalihah, F., Supramono, \& Abdullah. (2019). Blended Learning-Based Media Usage To Practice Problem Solving Skills. European Journal of Education Studies, 5(9), 166. https://doi.org/10.5281/zenodo.2544571

Sophonhiranrak, S., Suwannatthachote, P., \& Ngudgratoke, S. (2015). Factors Affecting Creative Problem Solving in the Blended Learning Environment: A Review of the Literature. Procedia - Social and Behavioral Sciences, 174(1982), 2130-2136. https://doi.org/10.1016/j.sbspro.2015.02.012

Wahyuni, E. (2018). Improving Studentsr Independence and Collaboration With Blended Learning. 5th International Conference on Community Development, 231, 613-616. https://doi.org/10.2991/amca-18.2018.170

Zambrano, J., Kirschner, F., Sweller, J., \& Kirschner, P. A. (2019). Effects of group experience and information distribution on collaborative learning. Instructional Science, 47(5), 531-550. https://doi.org/10.1007/s11251-019-09495-0 